\title{
The place of rhetoric in late republican law: some thoughts on pietas and the querela inofficiosi testamenti
}

This is the published version of the book chapter:

Cunningham, G. (2020) 'The place of rhetoric in late republican law: some thoughts on pietas and the querela inofficiosi testamenti'. In B. Spagnolo \& J. Sampson (eds.), Principle and pragmatism in Roman law. Hart Publishing, Oxford, pp. 79-98. URL: https://www.bloomsburyprofessional.com/uk/ principle-and-pragmatism-in-romanlaw-9781509938957

Published with the permission of Hart Publishing/Bloomsbury. 


\title{
The Place of Rhetoric in Late Republican Law: Some Thoughts on Pietas and the Querela Inofficiosi Testamenti
}

\author{
GRAEME CUNNINGHAM
}

The general understanding of modern scholarship on Roman law concludes that the discipline is based on scientific principle. ${ }^{1}$ This perspective informs not only our understanding of how Roman law operated among the ancients, but also modern interaction with the subject, not least in its application to contemporary domestic laws. ${ }^{2}$ Among Romanists, there has been enthusiasm for asserting scientific principle as the fundamental basis of the discipline. This is derived from an adherence to two connected historical narratives created in nineteenthcentury Germany and adopted with vigour by subsequent scholars. ${ }^{3}$ The first narrative is that of continuity. It asserts that law has undergone a progressive process since the decline of the Roman Empire in the West, by which it has moved in stages toward a recapturing of the scientific accomplishments of the Romans. ${ }^{4}$ The second narrative is that of science. It asserts that, during the later Republic period, under the guidance of professionalised jurists such as Quintus Mucius Scaevola pontifex, and after a singular injection of Greek categorical thought, Roman law became an autonomous, scientific system, free from extralegal considerations, such as the social and the economic. ${ }^{5}$ The achievement of

${ }^{1}$ DJ Osler, 'The Myth of European Legal History' (1997) 16 Rechtshistorisches Journal 393.

${ }^{2} \mathrm{R}$ Zimmermann, Roman Law, Contemporary Law, European Law: The Civilian Tradition Today (Oxford, Oxford University Press, 2001); R Zimmermann, 'Roman Law in the Modern World' in DEL Johnston (ed), The Cambridge Companion to Roman Law (New York, Cambridge University Press, 2015) 452, 453-58.

${ }^{3}$ F Schulz, History of Roman Legal Science, (Oxford, Oxford University Press, 1946).

${ }^{4}$ MP Gilmore, Argument from Roman Law in Political Thought, 1200-1600 (Cambridge, Cambridge University Press, 1941), 3; F Wieacker, A History of Private Law in Europe (AD Weir trans, Oxford, Oxford University Press, 1995), 27; JQ Whitman, The Legacy of Roman Law in the German Romantic Era (Princeton, Princeton University Press, 1990), 29; K Tuori, Ancient Roman Lawyers and Modern Legal Ideals: Studies on the Impact of Contemporary Concerns in the Interpretation of Ancient Roman Legal History, 2nd, corrected edn (Frankfurt am Main, Vittorio Klostermann, 2007).

${ }^{5}$ Twentieth-century adherents to this view include but are not limited to F Schulz, Principles of Roman Law (M Wolff trans, Oxford, Oxford University Press, 1936), 33-37; WAJ Watson, The Law 
science is the summum bonum and end-point of the teleological trajectory of legal continuity.

It is my intention to cast some doubt on this foundational myth of a scientific revolution in Roman law in the late Republic, and, by extension, on the narratives of continuity and science that rely upon its supposition. ${ }^{6}$ In order to do so, I will examine the extent to which legal change in the later Republic, the period of the theoretical inception of legal science, was decisively reliant upon extralegal considerations. In particular, I intend to argue that rhetoric was used in order to assert the existence of the socially understood normative value of pietas in the relationship between testators and potential heirs, and that a rhetorical proof of such a relationship was the postulate, or locus, upon which a change in the law was based.

To this end, the first point I will examine is the development and operation of the querela inofficiosi testamenti. The second point I raise will examine how pietas, as a socially understood concept within Roman culture, informed decisionmaking in succession disputes. This will require a twofold examination of the social understanding of the concept of pietas in the later Republic, alongside a study of its direct application in law.

\section{The Development and Operation of the Querela Inofficiosi Testamenti}

The querela inofficiosi testamenti came into use in the mid-first century BCE, a later addition to Roman succession law than the praetorian innovation bonorum possessio. The querela provided protection to expectant heirs against a testator who, for reasons beholden unto himself, had disinherited them through a will. Reasons for disinheriting expectant heirs are several and varied, some more rational than others. Roman law had been satisfied as a matter of general principle to afford to a testator the broad discretion to disinherit almost whomsoever he pleased: prodigal sons, wayward daughters, and inattentive spouses could all effectively be disinherited by testament. Some restrictions existed - not least the formal requirement

of Succession in the Later Roman Republic (Oxford, Oxford University Press, 1971), 155; A Schiavone, Nascita della giurisprudenza: Cultura aristocratica e pensiero giuridico nella Roma tardo repubblicana (Roma, Laterza, 1976), 95-110; A Schiavone, 'Forme normative e generi letterari. La cristallizzazione del ius civile e dell'editto fra tarda repubblica e primo principato' in E Dovere (ed), La codificazione del diritto dall'antico al moderno (Naples, Editoriale Scientifica, 1998) 51; BW Frier, The Rise of the Roman Jurists. Studies in Cicero's pro Caecina (Princeton, Princeton University Press, 1985), 159-63.

${ }^{6}$ Recent work has been done in a similar vein: OE Tellegen-Couperus, Quintilian and the Law: The Art of Persuasion in Law and Politics (Leuven, Leuven University Press, 2003); JW Cairns and PJ du Plessis (eds), Beyond Dogmatics: Law and Society in the Roman World (Edinburgh, Edinburgh University Press, 2007); PJ du Plessis (ed), New Frontiers: Law and Society in the Roman World (Edinburgh, Edinburgh University Press, 2013); PJ du Plessis (ed), Cicero's Law: Rethinking Roman Law of the Late Republic (Edinburgh, Edinburgh University Press, 2016); PJ du Plessis, C Ando and K Tuori (eds), The Oxford Handbook of Roman Law and Society (Oxford, Oxford University Press, 2016). 
in law to adhere to valid testamentary form. ${ }^{7}$ Bonorum possessio came to form a post-death restriction upon the realisation of the will of the testator but, as the operation of a claim was necessarily post mortem, its relationship to the writing of a testament takes on a different hue from measures designed to offer protection to expectant heirs during a testator's lifetime. Some protection for expectant heirs was provided through praeteritio. ${ }^{8}$ This rule set out that a testator had a duty by which he ought either expressly to institute as heirs those to whom in intestacy the property would pass, or, conversely, ought expressly to disinherit them. If no mention of such people was made in the will, they took on the title of praeteriti and the whole will could be undermined and property passed on under the civil law rules of intestacy. ${ }^{9}$ The protection afforded by praeteritio, as Leage cogently argues, is the lingering trace of the ancient idea that property was vested in the family and not the individual paterfamilias. ${ }^{10}$ This view is rooted in the idea that sui heredes were regarded in their father's lifetime as something approaching family property, socially if not legally. The result was that, for instance, in the ius civile, a son in potestas could be disinherited either by being named in the testament as disinherited or by an expression making it clear by identification that the intention of the testator is to disinherit him. Failure to do so could result in the will becoming void on challenge and falling into intestacy. Praeteritio therefore offered some protection to the family of the testator, insofar as the disinheritance of sui heredes must be explicitly expressed and formally enshrined in order to be free from challenge. Praeteritio, though providing some solace to a child fearful of the intentions of a disgruntled parent, was far from a perfect protection of his expected birth right. A testator with the determination to disinherit his disaffected kin need only, perhaps with some legal advice, construct a formally valid testament which identified those potential praeteriti whom he wished to divest. The ancient ius civile, in this respect, very much favoured the testator over the dispossessed potential heir, and allowed for disinheritance as long as it was explicitly expressed.

The querela developed as an attempted perfection of the protection afforded by praeteritio. It exceeded its antecedent in the protection it afforded to expectant heirs, and instituted a nascent philosophical change as to whom the law favoured the expectant heir could now truly expect the ability to challenge if disinherited unduly. As Johnston outlines:

Only with the evolution of the querela inofficiosi testamenti did Roman law arrive toward the end of the Republic at the principle that descendants (or ascendants) of a testator actually had a legitimate expectation of acquiring a share of his estate, by virtue of law rather than the testator's own fancy. ${ }^{11}$

\footnotetext{
${ }^{7}$ D. 31.88 .17 (Scaev. 3 Resp.).

${ }^{8}$ AM Prichard, Leage's Roman Private Law, 3rd edn (London, Macmillan, 1961), 146.

${ }^{9}$ Exceptions existed to this principle: women were under no obligation to disinherit as they had no sui heredes.

${ }^{10}$ Prichard (n 8), 246.

${ }^{11}$ DEL Johnston, The Roman Law of Trusts (Oxford, Oxford University Press, 1988), 3.
} 
The reasoning behind 'the evolution' of this change in the principle of protection of expectant heirs remains obscure. The most convincing explanation for its development is that it was rooted in the idea that a paterfamilias owed a duty to those in his power to provide for them after his death, especially to those with ties of close kinship. ${ }^{12}$ While the querela offered improved protection against the total arbitrariness of a testator, it was nevertheless far from a complete revision of the general principle of the freedom to testate which underpinned Roman succession law. ${ }^{13}$

The first, early justification given for hearing a challenge was based on the sanity of the testator when the will was made. The sources belie the authenticity of insanity as the actual cause for action, as the wide scope of what was meant by insane is perceptibly disingenuous, as can be seen in the jurist Marcian's definition:

The proposition on which an action for undutious will is raised is that the testators were of unsound mind when making the will. And by this is meant not that the testator was truly insane or incapacitated but that the will was properly formed but without a necessary concern for natural claims; for if he were really insane or incapacitated, the will is void. ${ }^{14}$

A worryingly low bar for insanity, indeed. Yet, as Marcian points out, true insanity would render any will void $a b$ initio as the testator would be furiosus. A will is considered iniustum if a testator lacks the capacity, testamenti factio, when making it. ${ }^{15}$ A generally insane person, therefore, could make a will, but only if he was lucid at the time the will was made; a person who was insane without lucid intervals was lacking in capacity and therefore could not make a valid will. ${ }^{16}$ Wills made before the onset of insanity remained valid despite a later decline in the mental health of the testator. So, given that a will made by a person who was insane at the time of making it was void $a b$ initio, it is clearly outside the boundaries of logic to assume that a challenge via the querela could reasonably be based on an insane testator, as there would, in fact, be no legally valid will to challenge at all. Rather, as $\mathrm{du}$ Plessis argues, the juristic conversation of insanity was a 'pretence as it is clear that insanity was not really the issue. ${ }^{17}$ What, then, was really at issue in a challenge for an undutiful will?

The fundamental criterion which ought to be fulfilled was that the testator had been 'undutiful' in the making of his will. This terminology is not brimming with clarity, yet it seems fair to suppose that the basic scenario is when the testator acts in a manner which is unjust towards the claimant. The issue, then, is not so much

\footnotetext{
${ }^{12}$ Prichard (n 8), 252. Further on Roman patronage, see RP Saller, Personal Patronage under the Early Empire (Cambridge, Cambridge University Press, 1982).

${ }^{13}$ The extension of legitimi to expectant heirs only began to take shape in the late fourth century $\mathrm{CE}$ before the reign of Theodosius II.

${ }^{14}$ D. 5.2 .2 (Marc. 4 Inst.).

${ }^{15}$ D. 28.1 .4 (Gai. 2 Inst.).

${ }^{16}$ D. 28.1.2 (Lab. 1 post. a Iav. Epit.).

${ }^{17}$ PJ du Plessis, Borkowski's Textbook on Roman Law, 5th edn (Oxford, Oxford University Press, 2015), 234.
} 
insanity as inequity. Yet, this realisation does little to aid our understanding of the exact circumstances in which a claim may be brought, or in what way the court of the centumviri exercised its discretion to allow these cases to be heard with any consistency.

One of the reasons the juristic sources identify as an underlying cause for challenge to a will was a misunderstanding between the testator and the claimant resulting in an undutiful disinheritance, as the jurist Marcellus writes:

To state that a will is undutious is to argue that one ought not to have been disinherited or overlooked. In general, this happens when parents disinherit or overlook their children from a misunderstanding. ${ }^{18}$

This falls outside what could be reasonably termed grounds of challenge by insanity, as misunderstandings are not the same as madness on the part of the testator. The pretence of insanity was a ruse to justify disregarding the testator's right to choose his heirs. It was also used as a reason for disregarding the civil law of succession. Inequity takes centre stage in considerations of when the querela could be brought, as Gaius tells us:

For parents ought not to be unjust to their children in wills. In general, they do this, making a poor judgement on their own offspring, when their opinion has been altered by the flatteries or machinations of stepmothers. ${ }^{19}$

Here, we are given clear evidence that injustice and inequity is at the heart of what constitutes an undutiful will. Gaius goes on to provide an example of when a misunderstanding between a testator and prospective heir can lead to an unjust and undutiful disinheritance: a child passed over by a father as a result of the intrigues of a begrudging stepmother. This example reveals that, rather than insanity of the testator being the reason for the use of the querela, an intuition of injustice is the pivotal factor in the challenge. However, this raises further issues. It is still not clear where the limitations of a potential challenge lie; moreover, it is even less clear how consistency could be attained where an intuition of injustice underpins a challenge. It is not incredible to envisage a situation in which every child feels unjustly cheated by every disinheritance, leading to the use of the querela with overzealous abandon. Restriction existed as to the degree of familial separation by which claims could be challenged, alongside other limitations, such as a personal bar through acquiescence to other terms in the will. Even so, a claim of pure dutifulness still made complaints under the querela relatively common. According to Ulpian:

It should be noted that claims against the undutiful are made often. It is possible for everyone to claim a lack of duty, parents as well as children. Yet one's cognates beyond the degree of brother would be better not concerning themselves with needless cost as they are not in a position to win. ${ }^{20}$

${ }^{18}$ D. 5.2 .3 (Marc. 4 Inst.).

${ }^{19}$ D. 5.2 .4 (Gai. ad leg. Glitiam).

${ }^{20}$ D. 5.2 .1 (Ulp. 14 ad Ed.). 
Challenges to the will as set out were reasonably common; those who were not sufficiently close to the deceased did not frequently press a challenge, however, as their degree of separation made them unable to succeed in a claim. As the querela could only be brought by those who would have inherited had the testator died intestate, the claims which succeeded were limited to those made by descendants, ascendants, brothers and sisters. ${ }^{21}$

The key phrase in Marcian's description of when the querela was applicable is when the will was regarded as being non ex officio pietatis. ${ }^{22}$ That is, without regard to the pietas that is required of a particular office, or relationship. The interplay between these two concepts is of prime significance in the reason for deciding the worthiness of a challenge. First, the relationship between the testator and the aggrieved claimant is of central importance to the merit of the claim, insofar as the status assigned to the parties - that is, how the interpersonal relationship is viewed institutionally - is the basis upon which the law itself assigns property transfers in the ius civile.

\section{Pietas in Roman Society and Law}

The Oxford Classical Dictionary defines pietas as, 'the typical Roman attitude of dutiful respect towards gods, fatherland, and parents and other kinsmen.23 Wagenvoort provides a good encapsulation of its general meaning, by outlining that the man who possesses pietas 'performed all his duties towards the deity and his fellow human beings fully and in every respect. ${ }^{24}$ In its broad sense, pietas was a pervasive, philosophical concept, entrenched in the mindset of the Roman and more broadly in Roman society. The nature of the concept is necessarily hierarchical, insofar as it was always a factor in a relative relationship, as Saller points out:

First, the emphasis is on duty rather than affection or compassion. Secondly, it is a virtue displayed primarily toward a high power, whether it be the gods, the fatherland, or parents. ${ }^{25}$

This is reflected in the cultural value attached to it in art and literature, particularly in Virgil. ${ }^{26}$ There is also evidence in inscription which stresses the virtue of pietas. ${ }^{27}$ Moreover, it is made clear in the reverence shown to it within the law.

\footnotetext{
${ }^{21}$ Later law changed the scope of claims under the querela.

${ }^{22}$ D. 5.2 .2 (Marc. 4 Inst.).

${ }^{23}$ NGL Hammond and HH Scullard (eds), The Oxford Classical Dictionary, 2nd edn (Oxford, Oxford University Press, 1970), 833.

${ }^{24}$ H Wagenvoort, Pietas: Selected Studies in Roman Religion (Leiden, Brill, 1980), 7.

${ }^{25}$ Saller (n 12), 105.

${ }^{26}$ For an overview of Virgil's concept of pietas, see Wagenvoort (n 24); J Farrell and MCJ Putnam (eds), A Companion to Vergil's Aeneid and its Tradition (Chichester, Wiley-Blackwell, 2010).

${ }^{27}$ A striking example is the Laudatio Turiae. See CIL VI 1572, 10-12;31-33. For a brief but informative sketch, see S Dixon, The Roman Family (Baltimore, John Hopkins University Press, 1992), 27-28.
} 
The virtue of pietas was in turn subdivided into three forms: in regard to parents; in regard to fatherland; and concerning divinity. ${ }^{28}$ Pietas has a religious undertone, rooting itself in a natural order. Its realisation, as Wissowa alludes to, is all-encompassing, a complete fulfilment of what is expected in duty from the individual to his surrounding world. Specific types of pietas for other relationships were also acknowledged, such as fraternal pietas. ${ }^{29}$ All forms were reliant upon the acknowledgement of an institutional status - that is, upon the realisation that the status of individuals in relation to each other changed their interaction at an institutional level. Therefore, the relationship between father and son, for instance, takes two forms, the true relationship of everyday life and the institutional relationship of status which is imposed in various social, moral and legal ways. Gardner draws the important distinction that 'in real life the Romans lived in families ... familia, being a legal construct. ${ }^{30}$ The familia is a legal concept subject to institutional convention and in this way the pietas between parents and children was both real, insofar as it was based on natural affinity, but also social, insofar as it was enforced by the relationship of social status. The duality of pietas between social order and familial affection is well accounted for in Dixon's description of 'a strong sentimental ideal of family feeling ... overlapped with and supplemented (by) the traditional sense of obligation. ${ }^{31}$

Key examples of pietas are related in Latin literature. Valerius Maximus, who is fundamentally concerned with parental pietas, provides seven examples, under the title de pietate erga parentes et fratres et patriam..$^{32}$ Most striking of these is the account of a young woman breastfeeding her imprisoned mother to sustain her life. ${ }^{33}$

Valerius Maximus sets this up as the archetypal example of pietas, a notion evidently held in some consensus, by the fact the Romans raised a temple to pietas at the site where the event took place. Three key points can be taken from this anecdote. First, we can see clearly that pietas was not strictly limited to fathers and sons but is dependent upon duty towards a kind of relationship, mother and daughter included. ${ }^{34}$ Second, we can see that acknowledgement of duty resulting from a hierarchy is essential to its function. The daughter exemplifies pietas through her loving devotion (deligere) to her mother, the affection born out of devotional duty, more so than sentimental affection. ${ }^{35}$ Third, that obsequium (deference) is a significant characteristic of the duty owed as part of pietas. ${ }^{36}$ The expression of this duty is provided by Valerius Maximus in a series of exempla which focus on

\footnotetext{
${ }^{28}$ This classification is set out in reference to Cicero's statement in Inv. rhet. 2.22.66.

${ }^{29}$ For a full study on fraternal pietas see CJ Bannon, The Brothers of Romulus: Fraternal Pietas in Roman Law, Literature, and Society (Princeton, Princeton University Press, 1997).

${ }^{30} \mathrm{JF}$ Gardner, Family and Familia in Roman Law and Life (Oxford, Oxford University Press, 1998), 1.

${ }^{31}$ Dixon (n 27), 30.

${ }^{32}$ Val. Max. 5.4. ('Concerning Pietas with Regard to Parents, Brothers and the Fatherland').

${ }^{33}$ Val. Max. 5.4.7.

${ }^{34}$ Saller (n 12), 108.

${ }^{35} \mathrm{ibid}, 105$ : 'the emphasis is on duty rather than affection'.

${ }^{36}$ JPVD Balsdon, Romans and Aliens (Chapel Hill, University of North Carolina Press, 1979), 18.
} 
paternal pietas: Coriolanus ceasing hostilities at his mother's behest; ${ }^{37}$ Scipio Africanus being driven by pietas towards his father's memory to defeat Hannibal; ${ }^{38}$ Lucius Manlius Torquatus's son threatening the tribune Pomponius to persuade the official to drop charges against his horrible father, despite the hardship he had endured in his father's power; ${ }^{39}$ Marcus Cotta, on taking the toga virilis, accusing his father's prosecutor; ${ }^{40}$ the tribune Gaius Flaminus coming down from the rosta at his father's orders out of respect for auctoritas patria; ${ }^{41}$ and the vestal virgin Claudia using her prestige to stop a tribune preventing her father's triumph. ${ }^{42}$ These examples from Valerius Maximus are generally seen in terms of exempla of good moral behaviour, a form which is usually attributed to rhetoric. As Saller suggests, 'in Roman society the experts at the invocation of the conventional values illustrated by Valerius Maximus were the rhetoricians, for whom exempla were the tools of persuasion. ${ }^{43}$ This is the established practice of rhetoricians in setting out moral goods with reference to social norms. Saller, however, takes these examples to be essentially fictionalised and detached from any purposive reality:

The rhetoricians' manipulation of virtues in debates over imaginary conflicts provides insights into the meanings and associations of moral values. The fact that these rhetorical exercises are fictitious and highly contrived does not diminish their value as evidence for the meanings of virtue and the logic of the Roman moral system. ${ }^{44}$

Certainly, some rhetorical debates were contrived and used explicitly for academic purposes but Saller, in my view, underplays the important practical role of rhetorical exempla, and the very evident fact that Valerius Maximus takes his examples of pietas from reality, not imagination. The exempla provided reveal that pietas was not the construction of a manipulated virtue but, rather, an extant, socially understood value, widely acknowledged within Roman society.

Pietas in the modern legal scholarship is confined to a simpler and less sophisticated notion of filial obedience. Schulz provides a good example of this limitation, where he only discusses pietas in relation to children obeying parents. For Schulz, the only legal impact of pietas was that it imposed a duty towards parental authority and therefore pietatis ratio was simply obsequium toward parents. ${ }^{45}$ In legal practice, this did not impose or create any obligations but, rather, meant that there was an obligation not to abuse parents. This is manifest in following what Schulz labels 'three legal rules': a child must not summon a parent to court without the permission of the praetor; a child must not bring actiones famosae against parents; and a

\footnotetext{
${ }^{37}$ Val. Max. 5.4.1.

${ }^{38}$ Val. Max. 5.4.2.

${ }^{39}$ Val. Max. 5.4.3.

${ }^{40}$ Val. Max. 5.4.4.

${ }^{41}$ Val. Max. 5.4.5.

${ }^{42}$ Val. Max. 5.4.6.

${ }^{43}$ Saller (n 12), 109.

${ }^{44}$ ibid, 110.

${ }^{45}$ Schulz's argument is founded on the Digest title D. 37.15.
} 
child must not effect execution against his parents. ${ }^{46}$ Schulz's view places the stress of parental relationships on the auctoritas of the father as a signifier of the creation of certain legal effects: that is, the effects of coming under the patria potestas. ${ }^{47}$ The focus is very legalistic and does not examine the relationship of parents and children in closer detail; it has scant regard to the operation of relationships within either the actual family or the legal familia. In this understanding, pietas is reduced to a broad notion of filial obedience, rather than the more nuanced interpretation that we derived from Valerius Maximus.

The narrow view of pietas as filial obedience and of its legal effect as a proscription on abusing parents is not displayed in the juristic sources. In social terms, the central theme of patria potestas was its characterisation by pietas. Rather than strict adherence to obsequium as subjection of the child to the whims of the father, the patria potestas of the paterfamilias was underpinned by an aversion to atrocitas, or the harsh and rigid imposition of authority. ${ }^{48}$ It is my view that to understand pietas merely as obsequium and to conflate obsequium with filial obligation is to misstep. This is shown in the literary sources, where, although the duty of obsequium is outlined as a defining theme, the affection of a real family bond is also present in pietas as a concept. Schulz's narrowing of the concept is not in keeping with these sources. Nor is it in keeping with the legal sources; for instance, in the Digest, we find the following:

It is said that when during a hunt a certain man killed his son, who had been committing adultery with his stepmother, the deified Hadrian banished him to an island [because he acted] more as a bandit in killing him than as [someone] with a father's right; for paternal power should be contingent on compassion, not brutality. ${ }^{49}$

Here, we are provided with a clear example of the law recognising that pietas constitutes more than the recognition of an obligation to filial obedience through obsequium; it restrains the father from exercising his rights to the letter of the law, lest he behave in such a way as to endanger the reciprocal feeling of pietas that ought to exist between father and son. This shows that Schulz's narrow interpretation does not represent the whole understanding of pietas in the Roman mind; pietas, rather than simply setting out three restrictions on the basis of parental deference, can, in fact, require a father not to act in the way ascribed by law to his patria potestas. The law in its strictest, literal interpretation is circumvented by an appeal to a conceptual idea, which outranks it, an unwritten obligation to behave with pietas which is here legally enshrined by imperial proclamation. This section is sufficient to show the narrowness of the limitation but does not reveal to us the means by which the Emperor Hadrian felt it incumbent upon himself to rule as he did. For this, other examples of pietas in the legal sources are illuminating.

\footnotetext{
${ }^{46}$ F Schulz, Classical Roman Law (Oxford, Oxford University Press, 1951), 160.

${ }^{47}$ ibid, $140-61$.

${ }^{48}$ Dixon (n 27), 47.

${ }^{49}$ D. 48.9 .5 (Marc. 14 Inst.).
} 
The jurists were more than happy to modify or circumvent the law in such a way as to consider pietas as a directly and implementable factor in construing legal rules. An example is found in the case where relatives provide alimenta for a fatherless child (pupillus) out of pietas. This personally bars them from recovery of that cost from the child's estate under the normal rules of unauthorised administration:

I replied that, if Titus supported his sister's daughter from a sense of duty [pietatis], he did not have an action against her on this account. ${ }^{50}$

We can clearly see that pietas is noted as directly affecting juristic argument. Nevertheless, we are left without much of an explanation as to what Modestinus meant when he employed the term. What can be seen, however, is that Schulz's limited view that pietas in legal terms is synonymous with filial obedience through obsequium is insufficient. The circumvention of the usual rules of unauthorised administration is not achieved by reference to the kind of relationships Schulz discusses but appears to be based on an appeal to the kind of pietas seen in Valerius Maximus. Indeed, supporting a sister's daughter out of pious duty is more akin to the actions described in Valerius Maximus 5.6.7 than it is to the prescriptive obligations outlined by Schulz. This is not an isolated example. Other passages from the Digest show the jurists circumventing standard legal rules by reference to the kind of broader 'social' pietas of the exempla in Pliny and Valerius Maximus, rather than to Schulz's narrower 'legal' pietas. For instance, the general rules of law applied to dowry can again be disregarded in favour of an appeal to pietas:

If a woman labours under the notion that she is required to give a dowry, she cannot recuperate anything given on that account; for underneath there remains the moral bond [pietatis], and a payment based on that reason cannot be recuperated. ${ }^{51}$

Again, this is not obviously limited to filial obedience. In fact, it has little to do with obsequium to parents. The stress here is on the fulfilment of the moral obligation arising out of a relationship, in this case, with her husband. I would suggest that this is more akin to the pietas of Valerius Maximus than it is to pure deference to authority. The pietas of the exempla circumvents or modifies the law, and fits no narrow legalistic interpretation of the term.

Further examples abound, where pietas is central to modifying the rules on untrustworthy tutors and curators:

Furthermore, even women are admitted, but only those who take this step under the compulsion of duty [pietate] and necessity, as for example, a mother. A nurse also and a grandmother can bring a charge. So can a sister; for in a case of a sister, there even exists a rescript of the deified Severus; and if there is any other woman whose deliberate sense of duty [pietatem] is perceived by the praetor although she does not go beyond

${ }^{50}$ D. 3.5.26.1 (Mod. 2 Resp.).

${ }^{51}$ D. 12.6.32.2 (Iul. 10 Dig.). 
the modesty of her sex, but was induced by her sense of duty [pietate] not to conceal the wrong beyond the pupilli, the praetor should allow her to make an accusation. ${ }^{52}$

Once more, the pietas in question here is not simple filial deference but depends, rather, on an appreciation of the broader notion. It is analogous to several of the examples provided in Valerius Maximus. Once more, the jurists commit to modification of the law based on arguments rooted in the broad 'social' understanding of pietas, and not a limited 'legalistic' one. A similar example makes the point clear:

But moreover, when it is a mother who appeals concerning the property of her son being ruined by a judgment, she should be granted a hearing out of reverence to family piety, and if she prefers to take on the preparation of the lawsuit, she is not regarded as bringing a disruptive action, even if initially she cannot defend the case. ${ }^{53}$

The concession made by law to pietas has ostensibly no link to authority here but, rather, to a mutual relationship of affection and duty. This mutuality is a symmetrical appreciation of the role of duty regarding pietas but it is not truly synallagmatic: there is no obligatory reciprocity but a unilateral moral obligation which is mirrored but non-dependent on particular action. Nor is there a determined obligation in the form of a legal imposition of particular action, as we see from our example. A mother can, and indeed ought, to protect her son's property by raising an action, based on the social practice of pietas. The interesting thing for present purposes is that the law gives way to this social demand, and the civil law is modified in favour of this social - not legal - reasoning.

One more example shows this social understanding of pietas being used directly to modify law:

But if the freedman has given his daughter a dowry, he does not appear to have defrauded his patron in respect of the amount of the dowry, because a father's duty [pietas] is not to be the cause of condemnation. ${ }^{54}$

Justinian's Institutes recall that the origin of Roman law may lie outwith written statement. ${ }^{55}$ Contained within the very fabric of the law is an appreciation of the unwritten nature of determinative socially understood values as important sources of law. The silence of the text on the nature of these unwritten laws goes beyond a mere tradition of customary acceptance of particular modes of behaviour, extending to the cultural appreciation of the underlying values which cause that behaviour. It is in this way that pietas, as a socially understood value, operates as the basis for law.

We find further discussion of pietas in the Rhetorica ad Herennium. Here the Auctor brings up pietas in his discussion of the division (partes) of law (ius). Of the six divisions of law - nature, statute, custom, precedent, equity and agreement ${ }^{56}$ - which

\footnotetext{
${ }^{52}$ D. 26.10.1.7 (Ulp. 35 ad Ed.).

${ }^{53}$ D. 49.5.1.1 (Ulp. 29 ad Ed.).

${ }^{54}$ D. 38.5.1.10 (Ulp. 44 ad Ed.).

${ }^{55}$ Inst. 1.2.3.

${ }^{56}$ Rhet. Her. 2.13.19.
} 
the Auctor sets out, he provides a specific example of each, except for nature, where he raises pietas. ${ }^{57}$ The provision given by the Auctor of natural law is the bond of children and parents:

Natural law is seen in the relationships formed from the reason of pietas; it is by this law that parents are nurtured by children and children by parents. ${ }^{58}$

Pietas is presented to us by the Auctor as a principle which is directly related to natural law, not only as a result of natural law but rather as an integral part of it, as a concept which is inherent to natural law. The ascription of pietas to natural law is made with little explanation, other than a simple assertion that it is an observable inference. The sentiment replicates that of Valerius Maximus in his assessment of the virtue of pietas. The difficulty here lies in our understanding of law, because the nurturing of children is not law in the same sense as property rights or delictual liability. Natural law provides an overarching superstructure to which man-made law is often referential and to which it is sometimes inextricably bound. That said, natural law is not enforceable in the same direct sense as man-made law. Therefore, its enforceability takes the form of social normativity and not legal obligation. Illtreatment of children by parents then - the failure to nourish - is a social and moral breach, rather than a legal one, in terms of how society enforces its standards.

Honorés distinction between appeals to particular types of argument put forward by the Romans in providing reasons for decision-making is of use here in formulating this thought, between what he calls 'appeals to rules of law', 'open arguments' (topoi or principles), 'the facts', and 'argumenta ex auctoritate' (specifically juristic authority).$^{59}$ In the instance where pietas governs the relationship between parents and children, in order to give not only a social-moral but also a legal dimension to that relationship based on natural law, the argument is principled or open, it concerns a topos. Winkel argues that the lack of a coherent hierarchy of sources was the cause of the need for open, topical arguments in decision-making. ${ }^{60}$ Winkel's classification is correct, insofar as the diversity of rationality for decision-making is less well defined than it is in modern civilian legal systems. However, although it engages a broad interpretation in decision-making, it does not provide us with an answer as to how open reasoning behind decisions in a case exists within a system which purportedly had developed a nascent scientific tendency. What is of more interest in the example with which we are presented here is how the open-argumentation (that is, topical rhetoric) is a cornerstone of legal argumentation, necessary for the creation of legal obligations.

In De oratore, Cicero, in the voice of his interlocutor Crassus, acknowledges the needs of the orator to make pronouncements on a variety of subjects. ${ }^{61}$ Among

\footnotetext{
${ }^{57}$ cf Cic., Inv. rhet. 2.21.62-68.

${ }^{58}$ Rhet. Her. 2.13.19.

${ }^{59}$ AM Honoré, 'Legal Reasoning in Rome and Today' (1973) 4 Cambrian Law Review 58, 84. The idea that Roman legal decision-making involved a plethora of approaches is worth bearing in mind.

${ }^{60}$ LC Winkel 'L'histore du droit, exemple d'une science interdisciplinaire' (1996) 9 Sartoniana 125.

${ }^{61}$ Cic., De or. I.55. It is worth reiterating that the nature of the dialogue means that neither Crassus nor Antonius can be conclusively regarded as the 'mouthpiece' of Cicero, that and some caveat must be
} 
these topics with which the orator must deal is pietas. ${ }^{62}$ Cicero points out that the orator's dabbling in more specialised topics results in some disgruntlement among the specialists:

All the academies and schools of philosophy will, I do believe, raise the cry that all these matters are their exclusive province, and in no way whatever the concern of the orator. ${ }^{63}$

On issues of philosophy and law, the technical specialisation of these topics makes knowledge of the subject an essential for informed speech. Apart from these more discrete topics, Cicero also includes friendship, harmony, equity and virtue. These subjects are less obviously accounted for than law and philosophy, which have easily understood parameters. The answer to their inclusion comes from the contention - made by Crassus later in the same interaction with Scaevola - that the expertise of the orator lies in the broader theme of 'human life and conduct.'. ${ }^{64}$ This statement - that the true province of the orator lies in human life and conduct - is revealing; and it is contested, in its fundamental terms, by neither Scaevola nor Antonius in Cicero's text. The implication is that the orator - through the technical process by which he acquires his argument, rhetoric - is properly to be understood first and foremost as an expert in human social interaction: human life and conduct. The orator, therefore, in making his pleadings, has a particular social expertise, from which he can draw the loci of his arguments.

Turning to the issue of the loci of arguments for the conclusion of equitable remedies, Cicero, in his Topica, points out the need to distinguish three types of speech in constructing an argument from particular places. Judicial speeches, which appeal to equity, concern different rhetorical origins from deliberative or encomiastic speeches, which deal in advantage and honour. Cicero explains the locus for arguments in judicial speeches. ${ }^{65} \mathrm{He}$ argues that each of these three forms of argumentation has, through the practice and theory of oratory and rhetoric, developed stylistic differences. In judicial argumentation (iuridicalis), the purpose of equitable remedy is to distinguish right from wrong.

The actual application of this kind of argumentation is outlined in the case of the will of a soldier in De oratore. At first impression, it appears that the decision here is made on legal grounds, specifically on a question of the civil law: does a son have a right to a legitimate share of his father's estate by virtue of being a son not explicitly named as disinherited? However, in reality, Cicero attributes the award of the estate to the rhetorical arguments of pietas used by Lucius Licinius Crassus in the course of the argument. ${ }^{66}$ Cicero's attribution reveals how the socially understood value of pietas has an actual application in legal decision-making.

given to claims made by either interlocutor as definitively the opinion of Cicero himself; see CEW Steel, Roman Oratory (Cambridge, Cambridge University Press, 2006), 73.

${ }^{62}$ Cic., De or. I.56.

${ }^{63}$ Cic., De or. I.56.

${ }^{64}$ Cic., De or. I.68.

${ }^{65}$ Cic., Top. XXIII, 91.

${ }^{66}$ Cic., De or. I.245. 


\section{Later Evidence for the Application of Pietas in the Querela Inofficiosi Testamenti}

It is right to say that, apart from the attestation of Valerius Maximus, the Auctor of the Rhetorica ad Herennium and Cicero, there is little evidence for the actual application of pietas as the ratio decidendi for decisions made in challenges under querela during the later Republican period. Nonetheless, we can be sure that it was applied as a key factor in the decision-making process. The jurists, as outlined, give verification of this fact. However, our source material is dishearteningly limited in providing us with an insight as to the exact mechanisms by which the querela was dependent on pietas as the decisive factor by which the centumviri were persuaded. Furthermore, the justification for the reasoning behind pietas overriding the civil law as a basis for decision-making remains shrouded in uncertainty. This uncertainty is behind the rise of the prevailing idea that a separation occurred between the law as set out by jurists in the first phase of a challenge, and an extra-legal second phase which began in pleadings before the centumviral court, where rhetoric was applied with little relation to the preceding legal phase. Despite this lack of sources from the late Republic, legal literature from later periods provides us with a discernible insight as to how pietas operated in relation to law in challenges for undutiful wills. In particular, the Codex Iustinianus provides a series of imperial rescripts which, though written at a much later period than that of the inception of the querela - and, as such, subject to the social and legal differences which the intervening centuries imply - mention claims of undutiful wills in their historical context, either directly, or as an analogous legal form through which other issues could be solved. These texts are useful, though it must be stressed imperfect, in providing us with evidence of the actual, practical relationship between law and rhetoric in the centumviral court in the period of the later Republic.

Before undertaking this examination, some consideration must be given to the substantive changes in succession law which occurred in the intervening time, which have a direct impact on the cases presented. First, obvious institutional changes separate the Republic from the Empire: the introduction of specific legal instruments with regard to succession law must be borne in mind to properly contextualise the law according to period. Second is the senatus consultum Orphitianum of $178 \mathrm{CE}$, during the reign of Marcus Aurelius. This made provision for children to make first claim on their mother's estate as legitimi under the praetorian rules of succession. This prevented fathers from limiting emancipated daughters from making wills through guardianship and also afforded children the same priority in inheritance from mothers' wills as they were due under fathers' wills, changing the dimension of the order of succession. ${ }^{67}$ Third,

\footnotetext{
${ }^{67}$ For a useful outline of the implications of the senatus consultum Orphitianum, see Gardner (n 30), 231-33. For a more doctrinal analysis see WW Buckland, A Manual of Roman Private Law, 2nd edn (Cambridge, Cambridge University Press, 1953), 373-74. Juristic references: D. 38.17; PS 4.8; Reg.Ulp. 26.7; Inst. 3.4.
} 
the edictal category of unde liberi was not conclusively in existence by the $50 \mathrm{~s} \mathrm{BCE}$ and therefore is of dubious application in regard to development of the querela in the mid-first century все. ${ }^{68}$ These changes to the law caused divergence in terms of substantive legal points but did not undermine the general integrity of the form of challenge for undutiful wills.

The first of the related rescripts found in the Codex Iustinianus is given by the Emperor Philip the Arab to a certain Nicanor and Papiniana, and deals directly with the querela, dating from $245 \mathrm{CE}$. The case concerns a mother offering gifts to strangers and certain children in order to deprive other children of their legal portion:

If, as you allege, your mother, in order to frustrate a complaint seeking to have her will set aside as undutiful, during her lifetime almost exhausted all her property by making gifts either to certain of her children or to strangers, and afterwards made you heirs to two-twelfths of her property and wanted to reduce that to nothing through legacies and testamentary requests, you do not unjustly desire to be aided by the provisions of the constitutions made concerning undutiful wills, as not having received your legal portion. ${ }^{69}$

The text provides us with a clear case of a challenge based on a mother neglecting her supposed duty to make provision in her will for her children. As the text dates from after $178 \mathrm{CE}$, the senatus consultum Orphitianum applies. Given that there is a use of legacies and testamentary requests (ie, fideicomissa) to delimit what was actually inherited to below a quarter of the estate, an immediate issue arises, as this is a reduction to below the value which ought to be apportioned to heirs under the lex Falcidia of 40 BCE. A quarter of the estate is recoverable for apportionment between named heirs on this ground alone, and combats legacy provisions which reduce the inheritance to nothing. ${ }^{70}$ However, the deliberate exhaustion of the estate through a series of gifts given to strangers and other children still frustrates the claimants from attaining an equitable amount in the will. Phillip the Arab, on noting this, points out that a remedy can be sought for the mother's cynical attempt to manipulate her property away from Nicanor and Papiniana, and can be redressed by a challenge under the querela. The challenge for an undutiful will is due, as such a claim would not be unjust in relation to the constitutions regarding the assignment of the legal portion. The text provides us with clear evidence that

\footnotetext{
${ }^{68}$ Watson (n 5), 83 points to the testament of Val. Max. 7.8.4 to deduce that had the category been in existence then bonorum possessio would have provided a more obvious remedy than the claim under querela inofficiosi testament. D. 2.2.23 is also of interest, insofar as it states that an emancipated son could claim under bonorum possessio contra tabulas but not bring the querela inofficiosi testamenti if disinherited, the implication being that before unde liberi was introduced, that is, before this text, only sui heredes had to be expressly named to be disinherited or instituted. Gardner (n 30), 3-8 points to some evidence of the existence of unde liberi and unde cognati by 66 BCE based on Val. Max. 7.7.2 but the documentary evidence remains inconclusive.

${ }^{69}$ C. 3.29.1 (Philip to Nicanor and Papiana, 19 August 245).

${ }^{70}$ Not only is the lex Falcidia a protection against the reduction of the estate to nothing, but also a senatusconsultum of a date between Hadrian and Vespasian. See D. 39.6.15 (Iul. 27 Dig.).
} 


\section{Graeme Cunningham}

the querela had survived in a discernible form to the third century CE. Moreover, it reveals that it is applied in scenarios where an injustice has occurred, due to nonreceipt of the prescribed legal portion. Other than that, this injustice presents us with a viable challenge; the text does not go further to reveal the bases on which an action would be successful. Nevertheless, the text frames the use of the querela in a similar vein to earlier juristic texts, and allows us to understand with confidence that claims for undutiful wills were made in circumstances similar to those set out by the classical jurists. The question in law here is whether the exhaustion of the property by the mother was done to frustrate a duty to provide for the legal portion to the claimant children. If the dispersal of gifts was designed to do this, the fact that the claim is made under provisions for undutious wills is indicative of the existence of a relationship of duty between mother and children beyond the provision for the remaining hereditas under the quarter apportionment rule of the lex Falcidia. The inference is that some portion of the gifts mortis causa can be recovered under a challenge of an undutiful will by aggrieved child heirs. The implication is that the duty by which that inheritance is owed is more akin to pietas than it is to the kind of apportionment set out in positive law. An examination of other rescripts sheds further light on this.

The rescript of Emperors Valerian and Gallien to Aetia from $256 \mathrm{CE}$ is of great interest in establishing the operation of the querela by reference to rhetorical conceptions and arguments. The scenario is typical of a claim for undutiful will: a daughter, Aetia, does not receive the allotted quarter portion as a child on the death of her father, due to the 'extravagant generosity' with which the father gave all his property to his son prior to his death. The decision is dependent on whether the son was emancipated or not, and the emperors' rescript makes provision for both circumstances:

If your father, by some whim of excessive kindness, gave all his belongings to his son, the latter either stayed in the power of his father, in which case, in an action to divide, it suits the judge to split the property in such a way that you entirely inherit the quarter of the share due on intestacy; or the son is emancipated, in which case, since a gift requires no outside assistance but is supported by its own strength, that is, no confirmation is required, the governor will, according to the constitutions, extend equitable relief following the pattern of a complaint to set a will aside as undutiful. ${ }^{71}$

The first permutation refers to the apportionment of wills under the lex Falcidia. Where the son - presumably Aetia's brother - to whom Aetia's father so generously granted all of his property so extravagantly, is not emancipated but still in the power of his father, Aetia ought to receive the legal portion which is legally owed to her: that is, the quarter share which would be due on intestacy. The remedy attested to here is well attested. It shares a factual and legal theme with the rescript of Philip

\footnotetext{
${ }^{71}$ C. 3.29.2 (Valerian and Gallien to Aetia, 27 July 256). In reading this, it is worth bearing in mind that gifts to unemancipated sons were generally invalid: C. 8.53.11 (Diocletian and Maximian to Septimius Dabinianus, 30 April 293). Gifts to emancipated sons were valid: C. 8.53.17 (Diocletian and Maximian to Hermia, 27 December 293).
} 
the Arab to Nicanor and Papiniana. Where a legal portion of an inheritance has been taken away from a child in order to benefit another child, the law offers the querela as a standard remedy for the recovery of the legal portion. The reasoning behind the exercise of a challenge of undutiful will goes no further than allowing a remedy for a recovery of an amount that ought to be inherited by prescription of positive law. The more significant scenario is that outlined in the case where the son is emancipated and beyond the scope of patria potestas.

In the second situation presented in the rescript, consideration is given to Aetia's position where the son to whom her father gave so generously is emancipated. The son's emancipation changes the complexion of the problem. If the son is emancipated, the gift remains legally valid. No direct legal remedy is offered to Aetia, and the gift of the father to his son stands in law. However, the imperial rescript does not leave Aetia without redress. Rather, we are told that the provincial magistrate is able to hear a challenge to assignment of the property. Although the gift is able to stand on its own strength (suis viribus), the constitutions (iuxta constitutiones) made provision for equitable relief to be sought by analogy to the querela (ad similitudinem inofficiosi querellae auxilium tibi aequitas impertiet). This is interesting for two reasons: first, despite a valid gift existing in law, the emperor is still willing to attempt to find Aetia a remedy on the grounds of equity (aequitas) through the constitutions; second, the argument is made by analogy to the querela, indicating that the decision reached upon equitable grounds against a legally valid gift in order to redress an unfairness in inheritance law shares the conceptual and mechanistic qualities of the querela itself.

The fact that the emperor felt comfortable making an analogy to the querela inofficiosi testamenti in this instance is not an isolated case. Later examples show that actions against 'undutious gifts' were introduced to the law by analogy to the querela. The interesting feature is the means by which the emperor frames the resolution of the issue: by following the solution provided by equitable remedy in extension from cases of challenges for undutious wills.

On what basis is the challenge made? We see that, by this stage, the pretence of insanity as the ground for a claim has long since evaporated. Aetia's case is clear that the father's motivation for favouring gifts is extravagant generosity (immensae liberalitatis), which, though unwise, is not insane. Accordingly, the development of a claim analogous to the querela need not dwell on the sanity of the testator - nor, in fact, did the challenge of undutiful will itself. The solution provided is born out of a feeling of equitability. This might seem a vague and insufficient method for solving the problem presented, were it not for the fact that, as we have seen, aequitas was a definable and understood concept in Roman society. This was the same for pietas. Rather than an appeal to woolly and esoteric ideals, these terms had social and legal meaning. Both of them relate to Aetia's case and to the decision of the emperors to allow a challenge to the apportionment of her father's estate based on the constitutions, despite the legal validity of the will at civil law.

We have seen that pietas forms the foundation for a claim under the querela. Aside from the requirements of status which entitle a claimant, pietas is the concept 
which asserts itself as the principal consideration in the ratio decidendi. Pietas is itself dependent on status and relationship. The form of pietas erga parentes is the definitive factor in establishing a moral and social duty, which, though not symmetrical, nevertheless creates reciprocal social and moral duties upon parents and children. The challenge to undutiful wills is the transformation of moral and social duty into legal obligation. That transformation is provided through the enforcement of the challenge in the centumviral court. That pietas and aequitas are used as tools of legal reasoning is also a transformation. These ideas change from moral and social virtues to legal concepts. Legal concepts can authoritatively decide legal remedies, and here we find that Aetia is provided with a challenge based on the legal authority of pietas and aequitas, as is done in a challenge for undutiful will, to provide her with legal redress.

A further example is provided in a rescript of the Emperors Diocletian and Maximian to a certain Calpurnia Aristaeneta, who sought a remedy for a prodigal son lavishing gifts unreasonably to the detriment of the familial property. Yet again, the redress is provided by analogy to a claim for undutiful will:

If your son used up his property through profligate and wasteful generosity, you may seek aid from the governor; and if on examination of the root of truth he judges that you, through your son, should have restitution of your rights as to the excessively large gifts, he will help you by rescinding the wrongful acts. Hence, for the purpose of setting the excessive gifts aside, you need no action similar to that of setting a will aside as undutiful. $^{72}$

The extension of the criteria of a claim for undutiful will to a claim for undutiful gifts is telling, on two points. First, it indicated that the emperor, in making these rescripts, was not averse to the application of analogy in legal reasoning. This, in itself, reveals the scope for rhetorical figures in the expansion of legal concepts, as dutiful gifts are viewed, ex similitudine, to share a fundamental essence with undutiful wills. The logic was that property divested unreasonably, whether inter vivos, or on death through testament, is challengeable on the grounds that it breaches a duty. The establishment of that duty, we can infer, is through the maternal relationship shared between Calpurnia Aristaeneta and her profligate son, the duty of pietas erga parentes. Second, based on this first inference, we can state with reasonable confidence that the reasoning which underpins a claim for undutiful wills is the same as that used for undutious gifts. The importance of this observation is that we can directly see the law expanding, purely on the basis of rhetorical reasoning: wills are challengeable when a duty of pietas is breached; undutiful wills are analogous to undutiful gifts, insofar as they both amount to the transfer of family property unreasonably against a duty of pietas to a relative; on the basis of this analogy, the remedy for the two ought to be the same. On the basis of this argument, therefore, a remedy similar to the querela inofficiosi testamenti is provided for undutiful gifts. This demonstrates not only that rhetoric provided the underlying

\footnotetext{
${ }^{72}$ C. 3.29.4 (Diocletian and Maximian to Calpurnia Aristaeneta, 10 February 286).
} 
ratio decidendi for decisions on undutiful gifts, insofar as it followed the pattern of undutiful wills in using breaches of pietas erga parentes as the definitional breach in allowing for a challenge, but also that rhetorical reasoning, through the use of analogy, was central to legal development, in expanding the scope of the remedy from challenges to wills to challenges to donations inter vivos.

The rescript to Calpurnia Aristaeneta is not an isolated case. Further rescripts follow a similar theme, addressing undutiful gifts by analogy to the remedy for undutiful wills. Examples of these are readily available: Cottabaeus was informed by Diocletian and Maximian that gifts given to emancipated sons which were 'extravagant and generous' are recoverable by children seeking 'the amount legally due to them' by analogy to the querela ${ }^{73}$ the same emperors informed a certain Demetriana that she was entitled to recover for extravagant gifts made to her brother by her father 'following the pattern of a complaint for setting undutiful wills aside, ${ }^{74}$ Ammianus was told by the same Augusti that, if his mother 'dissipated her property and bled her resources dry through extravagant generosity' to his younger brother, such gifts could be set aside following the logic 'from a complaint to set a will aside as undutiful'; ${ }^{75}$ the Emperor Constantius wrote to a certain Olybrius that

there is no doubt that the action concerning immoderate gifts has been introduced into the laws following the pattern of laws regarding undutiful wills, and in this respect both actions must be deemed as one or similar, both as to time and conditions. ${ }^{76}$

The use of a version of the challenge to undutiful gifts formulated on the basis of the challenge to undutiful wills is well established. The same logic is also extended, though with less evidence, to claims for undutiful dowry gifts, de inofficiosis dotibus. ${ }^{77}$

The reasoning which underpins these points is consistent with that used in the decision in the case of Calpurnia Aristaeneta. The fundamental points are as follows: first, undutiful gifts are analogous to undutiful wills and therefore the same remedy following the same criteria is a reasonable resolution to claims; second, the reason that these claims are analogous is that they fundamentally invoke pietas as the ratio decidendi.

\section{Concluding Remarks}

The idea of a scientific revolution in the later Republic has influenced scholarly interaction with Roman law to the present day. However, during the period in

\footnotetext{
${ }^{73}$ C. 3.29.5 (Diocletian and Maximian to Cottabeus, 28 February 286).

${ }^{74}$ C. 3.29.6 (Diocletian and Maximian to Demetriana, 26 April 286).

${ }^{75}$ C. 3.29.7 (Diocletian and Maximian to Ammianus, 10 May 286).

${ }^{76}$ C. 3.29.9 (Constantine to Olybrius, 19 May 361).

${ }^{77}$ C. 3.30.1 (Constantine to Maximus, 19 December 358).
} 


\section{Graeme Cunningham}

which Roman law is thought to have attained scientific qualities, legal decisionmakers relied on social, cultural and economic concepts to inform their judgments, rather than isolating themselves in a gapless system of law. In showing the impact of pietas on the development of the querela inofficiosi testamenti, I hope to have presented a nascent challenge to the narrative of Roman legal science, and widened the scope of enquiry to consider law within the society in which it functions. 